\title{
UMA ABORDAGEM ECOLINGUÍSTICA DAS PREPOSIÇÕES PORTUGUESAS
}

\author{
Lajla Katherine Rocha Simiāo
}

\begin{abstract}
RESUMO
Este artigo tem como tema o estudo das preposiçóes a partir da Ecologia das Relaçóes Espaciais (ERE) equiparado ao que é apresentado nas gramáticas normativas, dessa maneira, objetiva-se expor a ERE e contrasta-la com as descriçôes que as gramáticas fazem das preposiçóes a partir de uma perspectiva Ecolinguística.
\end{abstract}

PALAVRAS-CHAVE: Preposiçóes; ecologia das relaçóes espaciais; prototípicas.

\section{Introdução}

m 1971, Francisco da Silva Borba, em seu estudo sobre o Sistema de Preposiçôes do Português, já mencionava que "a língua só cumpre sua tarefa primordial - a comunicação - quando relaciona suas unidades básicas ou signos", dessa forma, as preposiçôes desempenham papel fundamental na comunicação ao estabelecerem relações lógicas entre os elementos da língua. Não somente por serem peças indispensáveis da estrutura linguística, as preposições são também, entre todas as categorias verbais, as de mais difícil domínio talvez pelas distintas formas como são apresentadas nos dicionários e gramáticas, além dos diversos matizes de significado a elas atribuídas, o que as torna material rico a ser pesquisado.

Assim como em Borba, as preposições já foram tema de algumas pesquisas com objetivos e perspectivas diversos. O que pretendo neste artigo é expor a Ecologia das Relaçóes Espaciais (ERE) e contrastá-la com a descrição que as gramáticas normativas fazem das preposiçóes. 
Para tanto, partimos do suporte teórico da Ecolinguística, que é o estudo das relações da língua com o meio ambiente, que pode ser natural, mental ou social. Foi no contexto dessa disciplina que surgiu a ecologia das relaçóes espaciais, de acordo com a qual todas as preposiçóes se reduzem à espacialidade, e não apenas as temporais, mas também as abstratas, ou nocionais, como Bernard Pottier já havia demonstrado desde a década de sessenta do século passado. (Pottier, 1962; Pottier, Audubert \& Pais, 1975)

Além de Pottier, Couto (2010) também tem demonstrado que o significado prototípico de toda preposição é espacial (locativo, de movimento). Em conformidade com os postulados da Ecolinguística, após formadas (movimento onomasiológico), as preposições geralmente podem adquirir outros significados, como sobre: depois de surgida para indicar superioridade, passou a indicar também assunto. Além disso, as preposições têm uma variada gama de usos diferentes ao serem retratadas num movimento semasiológico, ou seja, partindo dos nomes e indo na direção do que eles designam. Melhor dizendo, das preposiçóes para as relaçóes que elas representam. Lapa (1970), por exemplo, mostra diversos usos estilísticos derivados.

Serão utilizadas para este estudo a Moderna Gramática Portuguesa do Evanildo Bechara e a Nova Gramática do Português Contemporâneo de Celso Cunha e Lindley Cintra a fim de investigar que preposiçôes desviam do seu uso prototípico, quais não desviam, quais as posiçóes da Ecologia das Relaçóes Espaciais são representadas só por locução prepositiva, procurando uma explicação para isso, e quais preposições são também temporais.

No que subsegue, temos, na seção 2, um apanhado geral da nova disciplina Ecolinguística. Na seção 3, exponho a Ecologia das Relações Espaciais. $\mathrm{Na}$ seção 4, apresento a visão das gramáticas sobre as preposições. Na seção 5, finalmente, confronto o que foi exposto pela Ecologia das Relaçóes Espaciais com o que é apresentado nas gramáticas normativas sobre as preposições, exemplificando e procurando justificativas para certas ocorrências divergentes da ERE. A seção 6 contém as considerações finais.

\section{Arcabouço teórico ecolinguístico}

Um bom modo para contrapor as ideias expostas na ERE com o que está descrito nas gramáticas normativas sobre as preposiçóes é inserindo este estu- 
do no contexto de uma teoria linguística. Vou partir da Ecolinguística, que vem sendo definida desde o início da década de 70 por Einar Haugen como sendo "o estudo das interaçôes entre qualquer língua dada e seu meio ambiente” (apud COUTO, 2007b). Entende-se por 'meio ambiente' aqui o 'mundo', ou o aspecto dele a cujas relaçóes as preposiçôes se referem. Segundo Couto (2010:03/04), o objeto de estudo dessa disciplina é constituído essencialmente de interaçôes, ou seja, ela vê a língua como interação. Quanto ao seu meio ambiente, é o contexto em que se dão as interações, a fim de não coisificá-la. Nesse caso, temos o meio ambiente integral da língua, que compreende o meio ambiente natural, o mental e o social. No momento, daremos ênfase ao meio ambiente natural da língua, o qual é composto pela população (como conjunto de corpos físicos) juntamente com o território, ou melhor, os aspectos físicos e químicos do seu entorno. É nesse mundo físico que se encontra a ecologia das relaçóes espaciais.

O meio ambiente mental da língua é constituído pelo cérebro e pela mente, isto é, as conexóes neurais que se dão no interior do cérebro. $\mathrm{O}$ todo formado pela língua, pelo cérebro e pela mente constitui o ecossistema mental da língua. Por fim, temos o meio ambiente social da língua, formado pela sociedade, onde a língua é usada. É a população organizada socialmente, vista como um todo orgânico. O todo formado por língua e respectivo meio ambiente social é o ecossistema social da língua (COUTO, 2010:04).

Os três ecossistemas linguísticos não são estanques. "Há um inter-relacionamento constante entre eles. Todo fato linguístico pode, e deve ser encarado das três perspectivas" (COUTO, 2010:4). Assim sendo, a língua é considerada uma realidade biopsicossocial, embora às vezes seja necessário recortar determinado domínio de um dos ecossistemas a fim de se fazer um estudo pontual de determinado aspecto.

Objetivamos o estudo do que existe na ERE, confrontando-o com o que nos é apresentado nas gramáticas normativas sobre as preposiçóes. As preposiçóes indicam relaçóes que existem no mundo, o que provém de uma visão ecológica. Na Ecolinguística, elas são encaradas de modo holístico, partindo de uma postura onomasiológica, ou seja, aquela que parte da coisa (ou do conceito) para o nome que ela (ele) tem. É por esse motivo que o estudo se insere, em primeiro lugar, no ecossistema natural da língua. Entretanto, o mental também é ativado, secundariamente, uma vez que é no cérebro que se 
formam as relações. Por fim, é no consenso social, nos membros da população organizada socialmente, a sociedade, que tudo isso será confirmado (COUTO, 2010:04)

Apesar do que acaba de ser dito, ao avançarmos com a pesquisa e a temática em questão, uma postura semasiológica é também necessária. De acordo com Couto (2010:13), ela "consiste em partir dos nomes e ir na direção do que eles designam". Postura essa aqui mencionada, mas melhor abordada em outros estudos a respeito das preposiçôes. Sendo assim, é necessário expor detalhadamente a Ecologia das Relações Espaciais.

\section{Ecologia das relações espaciais}

Como dito anteriormente, pretende-se, nesta pesquisa, confrontar o que foi exposto pela Ecologia das Relaçóes Espaciais com o que nos é apresentado pelas gramáticas normativas a respeito das preposiçóes, as quais são vistas como palavras primordialmente relacionais, ou seja, são consideradas palavras de significado gramatical, categorias funcionais. Definição esta contestável aqui, pois elas estabelecem relaçóes palpáveis do mundo natural. A propósito disso, Couto afirma que (2010:04):

As preposiçóes espaciais são basicamente de dois tipos, as de posição e de movimento. Preposiçôes de posição, também chamadas de locativas, indicam as diversas posiçóes em que um objeto pode se encontrar, relativamente a outro. Por isso mesmo, pode-se dizer que são estáticas. Preposições de movimento, como o próprio nome já diz, são normalmente usadas com verbos de movimento. Elas podem indicar origem (venho de São Paulo), destino (vou a São Paulo) ou percurso (venho de carro desde São Paulo, passei por São Paulo).

As tentativas de representar a ERE no que tange às preposiçóes iniciaram-se no século XVII, época em que John Wilkins propôs uma representação bidimensional para as preposiçóes inglesas, o qual colocou, segundo Couto (2007b:90): 
Um observador em frente a um ponto de referência que consistia de dois círculos concêntricos. Primeiro, ele apresenta uma seta "para baixo", cujo resultado é "abaixo", bem como uma outra "para cima”, que resulta na relação "acima”. Em seguida, temos as seguintes relaçôes: a) "dentro" versus "fora", b) "para dentro" versus "para fora", c) "sobre" versus "sob", d) "aquém” versus "além”, e) "a/para" versus "de/desde". As seguintes relaçôes não são dicotômicas em seu modelo: $\mathrm{f}$ ) "sobre” (about), g) "acima" (over). Algumas posições em seu esquema não estão muito claras para mim. Por exemplo, h) "embaixo" (below) está entre o observador e o círculo, mas um pouco abaixo do diâmetro dele, não abaixo dele. Além do círculo central, de novo da perspectiva do observador, Wilkins inclui: i) "através de" e k) "além de". Fora do círculo maior, temos l) "a/para" (to) versus "de" (off). Finalmente, veem-se m) "após" (to the back of the observer, sic!) versus "antes" (in front of him, i.e., between him and the point of reference).

Mesmo apresentando algumas inconsistências, esta foi provavelmente a primeira tentativa na história dos estudos linguísticos de representar a Ecologia das Relações Espaciais.

Bernard Pottier também estudou as preposiçóes a partir do conceito de espacialidade. Ele apresentou as preposiçóes tidas como de movimento, as quais foram representadas no esquema da figura 1, embora inclua nele preposições que não são de movimento e até mesmo outras categorias de palavras.

Figura 1: Modelo de Pottier

\begin{tabular}{l|l}
$\rightarrow$ & $\mid \rightarrow$ \\
a & de \\
até & desde \\
para & por \\
ante & trás, após \\
diante & detrás \\
sob & sobre \\
sem & com
\end{tabular}




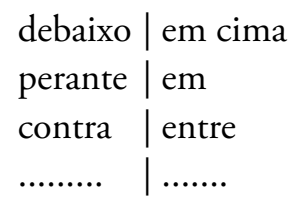

Fonte: POTTIER, apud COUTO (2007a)

Como já mencionado antes, toda preposição indica determinada posição prototípica, ou movimento prototípico, conforme Couto (2010:01). Como um subconjunto dessa relação, têm-se as preposições que indicam relações naturais, as quais existem na natureza independente de um observador, dentre elas estão: em, entre, sobre, sob.

Quanto às preposições de posição, temos o modelo que fora usado por John Wilkins no século XVII, retomado por Couto (1973: 45-46), refinado em Couto (1994) e aplicado às preposiçôes portuguesas em Couto (2010). Trata-se da já mencionada Ecologia das Relaçóes Espaciais, exposta na figura 2 (ver também Vandeloise, 1991).

Figura 2 - Preposições de posição

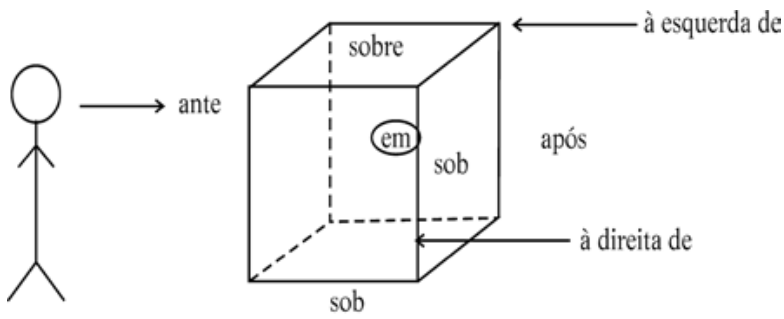

Fonte: COUTO, (2007a:122)

Couto (2007:91/2010:05) explica essa figura da seguinte maneira:

O ponto central dessa ecologia é a interioridade. Isso se deve ao fato de ela não exigir um observador. Assim, o caroço no interior de uma fruta está objetivamente lá, independentemente de haver alguém para observá-lo ou não. Por isso, ela é considerada 
a relação espacial não marcada, ao lado de seu oposto, a exterioridade. Não é de admirar que a preposição que a codifica $(\mathrm{em})$ seja a preposição espacial não-marcada, inclusive a que codifica a relação oposta (fora de), que não está na figura 2 .

Logo a seguir vêm as posiçóes de superioridade (sobre) e inferioridade $(s o b)$. As posições nelas contidas são também independentes de um observador. Sendo assim, elas constituem a segunda e a terceira posição mais natural, respectivamente.

Ainda consoante a Couto (2010), as posiçóes de anterioridade (ante, antes de) e posterioridade (após) dependem de um observador, uma vez que um objeto só pode estar antes ou depois de outro relativamente a ele. Couto (2010:05) afirma ainda que:

[...] se pensarmos em frente (na frente de) e traseira (atrás de), há entidades dotadas de frente e traseiro intrínsecos, como uma casa e um animal, por exemplo. Assim, independentemente de um observador, um objeto pode estar na frente da casa se estiver do lado da porta que dá para a rua.

Existem ainda as relaçóes de dexteridade (à direita de) e sinistridade ( $a$ esquerda de), as quais só são representadas por locuções prepositivas. De acordo com Couto (2010:05):

Elas são as mais marcadas de todas as que compóem a ecologia das relaçóes espaciais. Cruzando todas essas relaçóes, temos a dimensão verticalidade versus horizontalidade, de modo que todas as preposiçóes podem ser encaradas dessa perspectiva. A relação de superioridade/inferioridade passa, verticalmente, pelas preposiçóes sobre-em-sob, nessa ordem. A de anterioridade/ posterioridade se alinha ao longo da horizontalidade, redundando na sequência ante-em-após. Por fim, a dimensão lateralidade, que inclui dexteridade e sinistridade, passa por à direita de - em - à esquerda de. 
É válido lembrar que as relações representadas nas duas figuras não exaurem todas as relações espaciais possíveis. Existe ainda a posição de intermediação (entre). A figura 3 mostra que ela pode ser localizada entre o observador e o cubo. A figura mostra ainda que as relaçóes de direção de Pottier, mostradas na figura 1, podem ser incluídas na Ecologia das Relaçóes Espaciais da figura 2, o que mostra que essa ecologia pode incluir todas as relações espaciais, inclusive as de movimento, com a, para e até $(\rightarrow \mid)$ e de e desde $(\mid \rightarrow)$, ou seja, a Ecologia das Relaçóes Espaciais inclui as relaçóes de Pottier.

Figura 3 - Ecologia das Relaçóes Espaciais
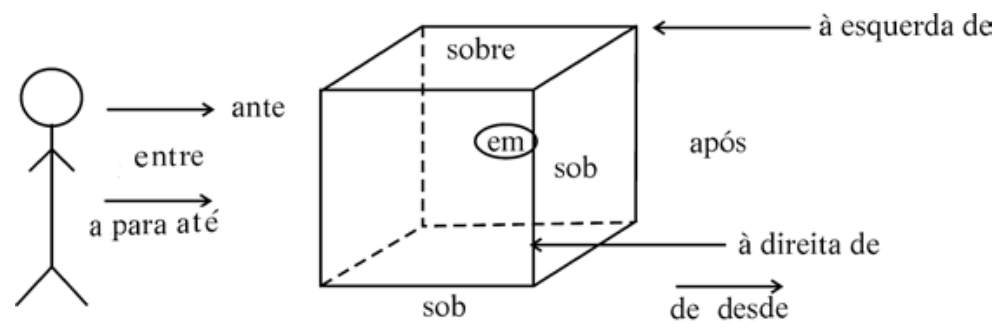

Fonte: Hildo Honório do Couto, não publicada.

No estudo das preposiçóes, assim como de qualquer palavra da língua, é necessário primeiro partir da base mostrada nas figuras 1,2 e 3, que é o momento onomasiológico, de emergência das palavras, mas, após formada, a palavra pode adquirir outros matizes de significação, que é o momento semasiológico, como demonstrou Couto (2010). Como se pôde ver, Pottier, assim como Couto, mostram que as preposiçóes têm origem espacial, de modo que as temporais e as nocionais (abstratas, aquelas que expressão relaçóes indicadas pelo contexto, mas na ERE elas também são redutíveis à espacialidade, mesmo que de forma não explícita) são derivadas delas.

De acordo com Couto (2007a), segundo o que se passa com as relaçóes espaciais, a relação temporal fundamental é a decorrente de interioridade, expressa em muitas línguas pela preposição em. "Assim, quando se diz que alguém nasceu 'no mês de abril' quer dizer que nasceu 'no interior' [...] do mês de abril”. (COUTO, 2007a:142). O que mostra que as relaçóes temporais são apenas um subconjunto das relaçóes espaciais. Couto (2007a) constata 
ainda que o espaço é tridimensional, o tempo é unidimensional, linear, o qual parece ser 'dinâmico', o que advém dele estar associado a movimento. Logo após a essa relação, temos a de anterioridade e posteridade que também são tidas como temporais. Em português ela está lexicalizada pelas preposiçóes ante e após, respectivamente. Essa relação tem a ver com a sequência linear do tempo. Tendo um ponto nesta linha, tudo que aconteceu antes dele pertence a anterioridade, chamado de passado. Tudo que acontecer depois dele, está no domínio da posteridade e é chamado de futuro. A relação de anterioridade/ posterioridade se alinha ao longo da horizontalidade, redundando na sequência ante-em-após.

Cunha (2010:10), afirma que "das preposições simples, algumas parecem ser incompatíveis com a temporalidade ou, então, só podem ser usadas temporalmente em contextos muito específicos. Entre elas temos com, sem, contra, entre, perante, sobre, sob, além das locuçóes prepositivas, à esquerda de, à direita de."

Das preposições (ou locuções prepositivas) da figura 1, praticamente todas podem ser usadas temporalmente. Segundo Couto (2010:10), "algumas delas parece terem se especializado, ou estão se especializando, no uso temporal, como após. Outras poderiam ser chamadas de espacio-temporais uma vez que podem ser usadas numa ou noutra significação. "

A respeito das locuçóes prepositivas, Couto (2010:11) defende a tese de que elas são:

redutíveis a duas preposiçóes simples intermediadas por um nome, ou outra categoria [...] Às vezes, elas constam de um advérbio mais uma preposição, como a maioria das ditas locuçôes prepositivas que substituem as preposiçôes simples da ecologia das relaçóes espaciais.

À vista disso, Couto diz que em vez de preposição composta ou locução prepositiva se poderia falar apenas em preposição, pois todas as construçôes que são classificadas como locuçóes prepositivas são constituídas de duas preposiçóes simples mais uma palavra lexical, em geral um substantivo, advérbio ou um adjetivo. Locuçóes como à maneira de, para fora de, por debaixo de, etc. são exemplos do que foi dito. 
Couto, portanto, demonstra que até mesmo adotando uma postura semasiológica, a variada gama de diferentes usos das preposiçóes se reduze ao significado espacial, temporal e, às vezes, espaciotemporal. "Há um núcleo significativo comum que, ao fim e ao cabo, desemboca no significado que emerge da ecologia das relaçóes espaciais". (COUTO, 2010:13)

\section{As preposições sob o olhar das gramáticas normativas}

As gramáticas selecionadas para realizar este estudo, Nova Gramática do Português Contemporâneo do Celso Cunha e Lindley Cintra e a Moderna Gramática do Português do Evanildo Bechara, definem de maneiras distintas o que vem a ser preposição, a qual para Bechara (2009:296) é "uma unidade linguística desprovida de independência [...] que se junta a substantivos, adjetivos, verbos e advérbios para marcar as relaçóes gramaticais que elas desempenham no discurso, quer nos grupos unitários nominais, quer nas oraçóes.” Já para Cunha (2008:569) "são palavras invariáveis que relacionam dois termos de uma oração, de tal modo que o sentido do primeiro (antecedente) é explicado ou completado pelo segundo (consequente)".

Mesmo de forma distinta, não há divergência entre esses autores, e outros tradicionais, de que as preposiçôes são unidades funcionais que relacionam elementos na sentença. Bechara (2009:296) afirma ainda que as preposiçóes não exercem "nenhum outro papel que não seja ser índice da função gramatical do termo que ela introduz", ou seja, são meras partículas gramaticais, categorias funcionais.

Ao desempenhar este papel, ambos os autores reafirmam que o termo anterior à preposição chama-se antecedente, e o posterior chama-se consequente. Cunha (2008:569) apresenta como exemplo:

preposição

antecedente consequente

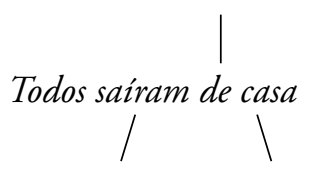

Quanto à forma, Cunha (2008:569) menciona que as preposiçóes podem ser classificadas em simples e compostas (ou locuçóes prepositivas). As preposiçóes simples, segundo ele, são expressas por um só vocábulo, as quais são: a, ante, após, 
até, com, contra, de, desde, em, entre, para, perante, por (per), sem, sob, sobre, trás.

Ambos os autores mostram que tais preposições se denominam também essenciais, palavras que só aparecem na língua para desempenhar o papel de preposição conforme afirma Bechara (2009:301).

São preposiçôes acidentais, de acordo com Bechara (2009:301), "as palavras que, perdendo seu valor e emprego primitivos, passaram a funcionar como preposiçōes". Como: afora, conforme, consoante, durante, exceto, fora, mediante, não obstante, tirante, segundo, senão, etc.

Já a locução prepositiva, segundo Bechara (2009:301), "é o grupo de palavras com valor e emprego de uma preposição". Constituída de dois ou mais vocábulos, seguida, geralmente, das preposiçôes simples de, a ou com. Alguns exemplos apresentados por Cunha (2008:570) são: a despeito de, de acordo com, em frente a, por diante de, em torno de, junto a, a fim de, etc.

Bechara e Cunha, dessa forma, definem as preposiçóes se voltando para sua função gramatical, apenas como um elemento de ligação na frase ou oração, no entanto, ao adotarem uma postura semântica, como veremos a seguir, eles se contradizem ao mostrarem que elas apresentam uma significação, não sendo vazias de significado, demonstrando inclusive seu emprego, seu uso.

Bechara (2009:298), à vista disso, afirma que cada preposição tem o seu significado fundamental, primário, do qual desdobram-se outros significados contextuais (sentido). Ele menciona ainda que essas acepçóes emergem de forma particular a partir do nosso conhecimento de mundo.

A significação das preposiçóes, seu significado fundamental e os contextuais, serão melhor evidenciados na próxima seção ao contrapormos as ideias expostas pela ERE e as presentes nas gramáticas normativas, pois interessa a Couto o valor semântico ao demonstrar as relaçóes que cada preposição designam.

Mesmo adotando essa postura voltada para a semântica, em algum momento ou outro, ambos os autores levam em consideração a função relacional "pura" dessas preposiçôes, ou seja, desconsideram o sentido da preposição, de modo a considera-la como um simples elo sintático, vazio de conteúdo significativo. Vejamos o exemplo a seguir encontrado em Cunha (2008:572):

1) Viajei com Pedro

2) Concordo com você 
A preposição com, nos dois casos, exprime a ideia de "associação", "companhia", a qual se mostra mais presente no primeiro exemplo, pois, no segundo, "o uso da partícula com após o verbo concordar, por ser construção já fixada do idioma, provoca um esvaecimento do conteúdo significativo de "associação", "companhia”, em favor da função relacional pura." (Cunha, 2008:573) Nesses casos, despreza-se o sentido da preposição e a considera apenas uma partícula de relação, vazia de conteúdo significativo.

Ambos os autores demonstram que a intensidade significativa da preposição depende do tipo de relação sintática por ela estabelecida, ou melhor, a semântica aqui pontuada por eles é dependente da sintaxe, o que pode ser contestada pela ERE, a qual acredita que as preposiçóes desempenham relaçóes existentes na natureza.

Além disso, outros tópicos sobre as preposições são abordados nas gramáticas, como: as relaçóes fixas, necessárias ou livres que estas unidades desempenham; a combinação (acúmulo) de preposiçóes; combinação e contração com outras palavras; a preposição e sua posição conforme as relaçóes sintáticas. Estes demais assuntos, no entanto, não são relevantes para nossa pesquisa. Passemos, então, à comparação entre as ideias apresentadas pela ERE e pelas gramáticas.

\section{Preposições: gramática normativa x ecologia das relações espaciais}

Da perspectiva da Ecologia das Relaçóes Espaciais, Couto (2010:15) relata que "as preposiçóes não são vazias de significado, uma vez que contribuem para a função referencial da linguagem e, por isso, para sua função primordial, que é a comunicação", ou seja, as preposiçôes contribuem muito para a mensagem, indo além de ser apenas um elemento relacional de função gramatical. Couto (2010:15) confirma essa ideia, por exemplo, "se dissermos este livro é de Camóes estaremos falando de uma situação muito diferente das que seriam descritas por este livro é sobre Camóes e este livro é contra Camóes, respectivamente". Notamos, assim, que as mensagens contidas nos enunciados se distinguiram apenas pela troca das preposiçóes,

Bechara, entretanto, (2009/2010) contradiz essa ideia ao demonstrar, num primeiro momento, que as preposiçóes não desempenham outro papel a não ser o de 'índice da função gramatical'. Vai além, dizendo que elas apare- 
cem nos discursos por 'servidão gramatical', como um mero indicador da função sintática. Mesmo no momento em que trata as preposições de uma perspectiva semântica, Bechara demonstra que o significado dessas preposições é dependente das relaçóes estabelecidas entre os elementos da frase, oração. $\mathrm{O}$ que evidencia sua predileção pelo aspecto sintático, tendo as preposições como meros elementos de função gramatical.

Já Cunha (2008:570) equipara-se, em parte, à ERE ao evidenciar que a relação que se estabelece entre as palavras ligadas por meio de preposição pode exprimir movimento ou uma situação resultante do movimento, os quais podem ser considerados em referência a espaço, tempo ou noção, como visto em Pottier. Por exemplo, a preposição de estabelece uma relação, segundo Cunha (2008:571):

1) Espacial em:

Todos saíram de casa.

Origem

2) Temporal em:

Trabalha de 8 às 8 todos os dias.

3) Nocional em:

Livro de Pedro

Posse

Em síntese, do mesmo modo como em Pottier e Couto, Cunha (2008:572), numa postura semântica, diz que apesar dos diversos matizes significativos das preposições, é possível estabelecer uma significação fundamental, marcada pela expressão de movimento ou de situação resultante e aplicável aos campos espacial, temporal e nocional, isto é, de acordo com a ERE, a significação das preposiçóes está indicada por uma determinada posição prototípica, as quais podem se deslocar para posiçôes contíguas.

Logo, percebemos que as preposiçóes expostas em Cunha pouco desviaram do uso prototípico espacial (locativo, de movimento). Apenas as preposiçôes com e sem não apresentam um significado claramente espacial para ele, classificando-as apenas como nocionais, por exemplo (Cunha, 2008): 
1) Saia do hotel com o sol já alto.

Simultaneidade

2) O sol subia no céu azul sem nuvens.

Ausência

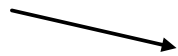

Ainda com o propósito de demonstrar quais preposiçóes desviam e quais não desviam do uso prototípico exposto pela ERE, pude perceber que Bechara, ao tentar demarcar os significados fundamentais de cada preposição (significado prototípico), se contradiz em alguns momentos, ele afirma que:

O sistema preposicional do português, do ponto de vista semântico, se divide em dois campos centrais: um que se caracteriza pelo traço "dinamicidade" (física ou figurada) e outro em que os traços de noçôes "estáticas" e "dinâmicas" são indiferentemente marcados ambos, tanto em referência ao espaço quanto ao tempo. Ao primeiro campo pertencem: $a$, contra, até, para, por, de e desde; ao segundo: ante, perante, após, trás, sob, sobre, com, sem, em e entre. (Bechara, 2010:291)

Ao contrastar o que foi exposto por ele neste momento com o que é mostrado pela ERE, notamos que, aparentemente, as preposiçóes que desviam do uso prototípico, segundo ele, seriam as contidas no primeiro campo e as que não desviam estão compreendidas no segundo. Contudo, Bechara vai além, ele subdivide estes dois grupos em subgrupos e estes em outros subgrupos. São nessas subdivisóes que encontramos a contradição. Segundo ele:

O primeiro grupo admite divisão em dois subgrupos: a) movimento de aproximação ao ponto de chegada (a, contra, até, para); b) movimento de afastamento (de, desde). A preposição por se mostra compatível com as duas noçôes [...] O primeiro subgrupo ainda se pode dividir em duas outras noçóes suplementares: a) "chegada ao limite" (a, até, contra, sendo que a contra se adiciona a noção de "limite como obstáculo" ou "confrontamento"); b) "mera direçấo" ou "direção de demora" (para). O segundo subgrupo 
também admite divisão em duas outras noçôes de afastamento: a) "origem" (de); b) "mero afastamento" (desde). O segundo grupo admite divisão em dois subgrupos: a) situação definida e concreta (ante, perante, após, trás, sob, sobre); b) situação mais imprecisa (com, sem, em, entre). O primeiro subgrupo acima ainda se pode dividir em duas outras noçôes suplementares: a) "situação horizontal" (ante, perante, após, trás); b) "situaçâo vertical" (sob, sobre). O segundo subgrupo também admite divisão em duas outras noçôes suplementares: a) "copresença", distribuída em "positiva" (com) e "negativa" (sem); b) em que a noçâo de "limite" [...] marca a preposição entre. (Bechara, 2010:291/292)

Esses traços semânticos podem ser melhor visualizados na figura 4, em que se encontra o resumo do sistema preposicional do português em conformidade com Bechara (2009/2010).

Figura 4: Traços semânticos

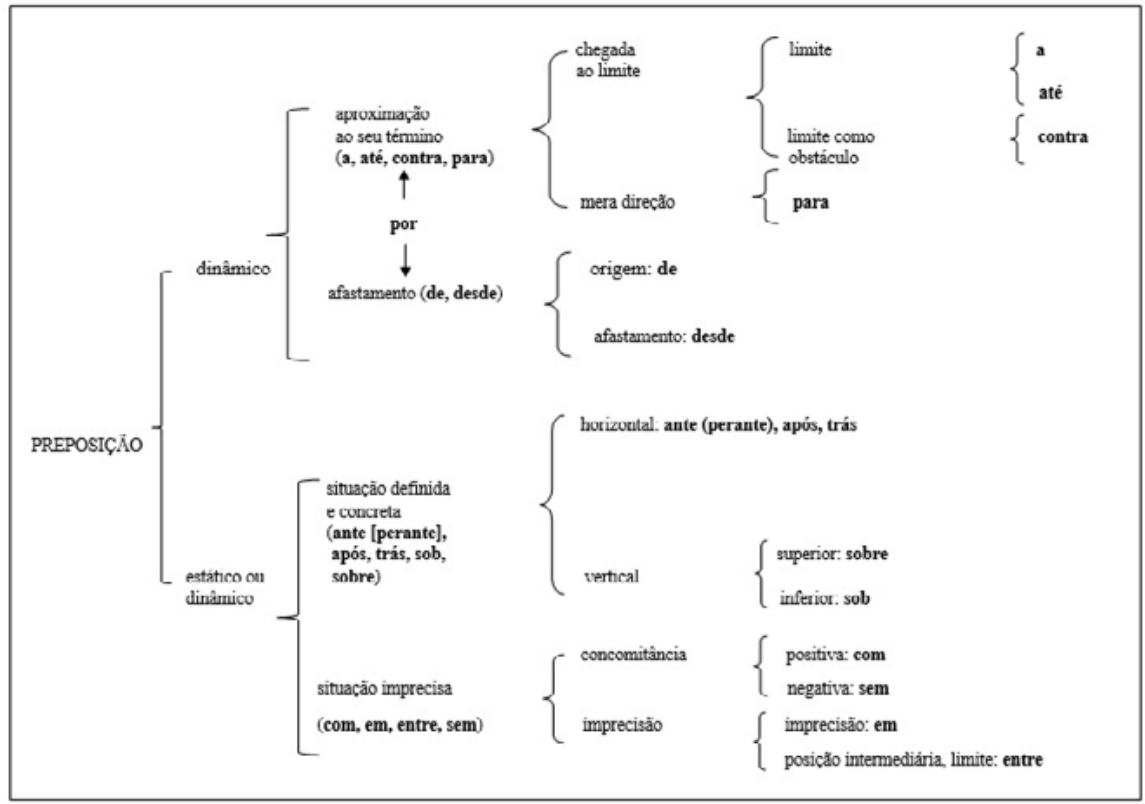

Fonte: BECHARA (2010:292) 
Se levado em consideração apenas o primeiro subgrupo, percebemos que se depreende, de forma clara, quais preposiçôes desviam e não desviam do uso prototípico espacial, porém, ao considerar as subdivisóes, depreende-se de todas elas noçóes complementares de espacialidade, o que evidencia a contradição de Bechara, e reforça as ideias expostas pela ERE de que todos os usos das preposiçóes se reduzem a um significado prototípico de cunho espacial. Os subgrupos que talvez demonstrassem um traço que desvia do uso prototípico seria o de "copresença", marcado, novamente, pelas preposiçóes com e sem.

A respeito das preposiçóes temporais, a ERE as classifica como um subconjunto das espaciais. Dessa maneira, para Cunha (2008), as preposiçóes que também são temporais são: a, ante, após, até, de, desde, em, entre, para, por (per), sob, sobre. A preposição trás, que não foi mencionada, talvez possa ser utilizada com a noçáo de temporalidade se representada pela locução prepositiva depois de, no entanto, Cunha não faz alusão a isso. Ele não classifica essa preposição simples, pois a considera já arcaizada, substituindo-a pela locução.

Como visto, Cunha (2008:591/592) classifica as preposiçóes sob e sobre como sendo também temporais, mas Couto (2010:10) afirma que, "trata-se, porém, de construçóes arcaizantes", vejamos:

1) A Companhia só voltou a se instalar no Brasil em 1841, sob Pedro II Imperador.

2) Sobre tarde descíamos à praia ou íamos ao Passeio Público, fazendo ele os seus cálculo, eu os meus sonhos.

Quanto à Bechara, as preposiçôes que denotam temporalidade, e que são classificadas por ele, são: $a$, de, em, entre, para, por (per). No caso da preposição entre, considerada por ele, e Cunha, como posição intermediária no tempo, percebemos que a marca de temporalidade se dá devido a esta preposiçáo acompanhar um elemento posterior (consequente) que remete à temporalidade, Cunha (2008:586) aponta como exemplo:

1) Todos os barcos se perdem entre o passado e o futuro.

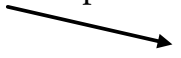

Houve um esvaecimento do conteúdo significativo.

Bechara não evidencia o emprego, ou uso, das preposiçóes: ante, desde, perante, sem, sob, sobre, após, trás, mas na figura 4 é possível verificar as noçóes que elas expressam. Possivelmente, Bechara não se preocupa em classificar todas as preposiçóes por adotar uma perspectiva mais sintática que semântica em sua análise. 
Com relação às locuções prepositivas, as posições da ERE representadas somente por locuçóes, de acordo com Couto (2010), seriam a sinistridade e dexteridade, contidas na dimensão lateralidade, as quais são expressas por: $\grave{a}$ direita de e à esquerda de. Bechara e Cunha, entretanto, não mencionam essas posiçooes específicas, mas fazem referência à dimensão lateralidade ao usarem como exemplo a locução ao lado de. Talvez essa menção ocorra por ela ser mais usual que as outras duas locuçóes. As outras posições da figura 3 são representadas também por preposições simples, o que pode ser evidenciado tanto na ERE, como nas gramáticas.

Como se pôde ver acima, o que basicamente Cunha adota, para o estudo das preposiçóes, são as relaçóes do esquema de Pottier, que podem ser inseridas de forma ampliada na Ecologia das Relaçóes Espaciais. De modo que, as definiçóes, as significaçóes e valores semânticos dessas preposiçóes convergem com o que é exposto na ERE, sendo poucos os desvios dos protótipos espaciais. Já Bechara apresenta uma visão mais destoante sobre as preposiçóes, mas que se analisada em seus por menores, como as vistas no quadro dos traços semânticos, perceberemos que talvez todos os usos das preposiçóes, mencionadas por ele, reduzam-se a um significado prototípico de cunho espacial.

\section{Considerações finais}

O objetivo principal neste artigo foi expor a Ecologia das Relações Espaciais (ERE) e contrastá-la com a descrição que as gramáticas fazem das preposiçóes, com o intuito de demonstrar quais preposiçóes desviam do seu uso prototípico, quais não desviam, quais as posiçóes da ERE são representadas só por locução prepositiva, procurando uma explicação para isso, e quais preposiçóes são também temporais.

Nesse sentido, vimos que, na ERE, todas as preposições indicam relaçóes prototipicamente espaciais e as demais nada mais são que derivaçóes dessas relaçóes. Sendo assim, por mais divergente que pareça determinado uso, ele tem sempre um significado nuclear subjacente à espacialidade. No entanto, Bechara apresenta ideias divergentes ao considerar que mesmo apresentando um significado fundamental, ele nem sempre está relacionado à espacialidade, como tentou demonstrar em sua classificação semântica, mas que ao compara- 
-la à ERE, foi possível perceber contradiçôes quanto a isso, bem expressas em seu quadro de traços semânticos, expresso pela figura 4 .

Já as ideias de Cunha a respeito não divergem tanto por ele adotar uma visão pautada no esquema de Pottier, em que a significação fundamental das preposições é marcada pela expressão de movimento ou de situação resultante, e aplicável aos campos espacial, temporal e nocional. Talvez o que mais destoa da ERE, conforme os dois autores, sejam as locuçóes prepositivas, por ambos não abordarem todas as posiçóes expostas no cubo da Ecologia das Relaçóes Espaciais.

Além dos objetivos aqui estabelecidos, outra questão foi constatada. Ambos os autores se contradizem ao ficarem presos, em muitos momentos, à função gramatical que as preposições estabelecem. Bechara e Cunha demonstram, a priori e de forma contraditória, que a significação das preposições depende do tipo de relação sintática por elas estabelecido. A postura semântica que eles adotam é, aqui, dependente da sintaxe. Essa visão, porém, é contestada pela ERE, a qual acredita que as preposiçóes desempenham relaçóes existentes na natureza.

Sendo assim, percebemos que as ideias de Cunha, ao concordar em parte com a ERE, reforçam os conceitos de relação espacial presentes na Ecologia das Relaçóes Espaciais, o que talvez ocorreu por sua postura mais voltada à semântica que à sintaxe, o que é contrário as pesquisas já feitas. Quanto a Bechara, por ele adotar uma perspectiva sintática, suas ideias acabam divergindo das expostas na ERE, mas num momento de análise semântica, ele deixa transparecer ideias que convergem com as evidenciadas pela Ecologia das Relaçóes Espaciais, mesmo que de forma contraditória.

\section{Referências}

BECHARA, Evanildo. Moderna Gramática Portuguesa. Rio de Janeiro, Nova Fronteira, 2009.

BECHARA, Evanildo. Moderna Gramática Escolar da Lingua Portuguesa. Rio de Janeiro, Nova Fronteira, 2010.

BORBA, Francisco da Silva. Sistema de preposiçóes em português. Universidade de São Paulo, tese de livre-docência, 1971.

COUTO, Hildo Honório. Os conetivos. Dissertação de mestrado, FFLCH-USP. 1973. 
COUTO, Hildo Honório. Ecolinguistica - Estudo das relaçóes entre língua e meio ambiente. Brasília, Thesaurus, 2007a.

COUTO, Hildo Honório. Ecologia das relaçôes espaciais - as preposiçóes do crioulo guineense. Papia 17. 2007b. p. 80-11.

COUTO, Hildo Honório. Ecologia das preposiçôes espaciais portuguesas. Lusorama. 2010. p. 83-84.

COUTO, Hildo Honório. Onomasiologia e semasiologia revisitadas pela ecolinguistica. Revista de estudos da linguagem. v. 20, n. 2. 2012. p. 183-210.

CUNHA, Celso \& CINTRA, Lindley. Nova Gramática do Português Contemporâneo. Rio de Janeiro: Nova Fronteira, 3a ed. 2008.

LAPA, M. Rodrigues. Estilistica da língua portuguesa. Rio de Janeiro: Livraria Acadêmica, 1970, 6a ed.

POTTIER, B. 1962. Systématique des éléments de relation: étude de morphosyntaxe structurale romane. Paris: Librairie Klincksieck, 1962.

POTTIER, B; AUDUBERT, A. \& PAIS, C. T. Estruturas linguisticas do português. São Paulo: DIFEL, 1975, $3^{\text {a }}$ ed.

VANDELOISE, Claude. Spatial prepositions: A case study from French. Chicago: The University of Chicago Press, 1991.

\section{AN APPROACH ECOLINGUISTICS OF PREPOSITIONS PORTUGUESE}

ABSTRACT: This article focuses on the study of prepositions from the Ecology of Spatial Relations (ERE) equivalent to what is presented in normative grammars, this way, the objective is to expose the ERE and contrasts it with the descriptions grammars do prepositions from a perspective Ecolinguistics.

KEYWORDS: Prepositions; Ecology of Spatial Relations; Prototypical.

Recebido em: 21/05/2016 Aprovado em: 18/10/2016 